\section{TRENDS IN INTERNATIONAL ARMS TRANSFERS, 2019}

PIETER D. WEZEMAN, AUDE FLEURANT, ALEXANDRA KUIMOVA, DIEGO LOPES DA SILVA, NAN TIAN AND SIEMON T. WEZEMAN

The volume of international transfers of major arms in 2015-19 was 5.5 per cent higher than in 2010-14 and 20 per cent higher than in 2005-2009 (see figure 1). The five largest exporters in 2015-19 were the United States, Russia, France, Germany and China (see table 1). The five largest importers were Saudi Arabia, India, Egypt, Australia and China (see table 2, page 6). Between 2010-14 and 2015-19, there were increases in arms transfers to the Middle East (by 61 per cent) and to Europe (3.2 per cent), while there were decreases in the transfers to Africa ( -16 per cent), the Americas ( -40 per cent) and Asia and Oceania (-7.9 per cent).

From 9 March 2020 the freely accessible SIPRI Arms Transfers Database includes updated data on arms transfers for 1950-2019. ${ }^{1}$ Based on the new data, this Fact Sheet presents global trends in arms exports and arms imports and highlights selected issues related to arms transfers.

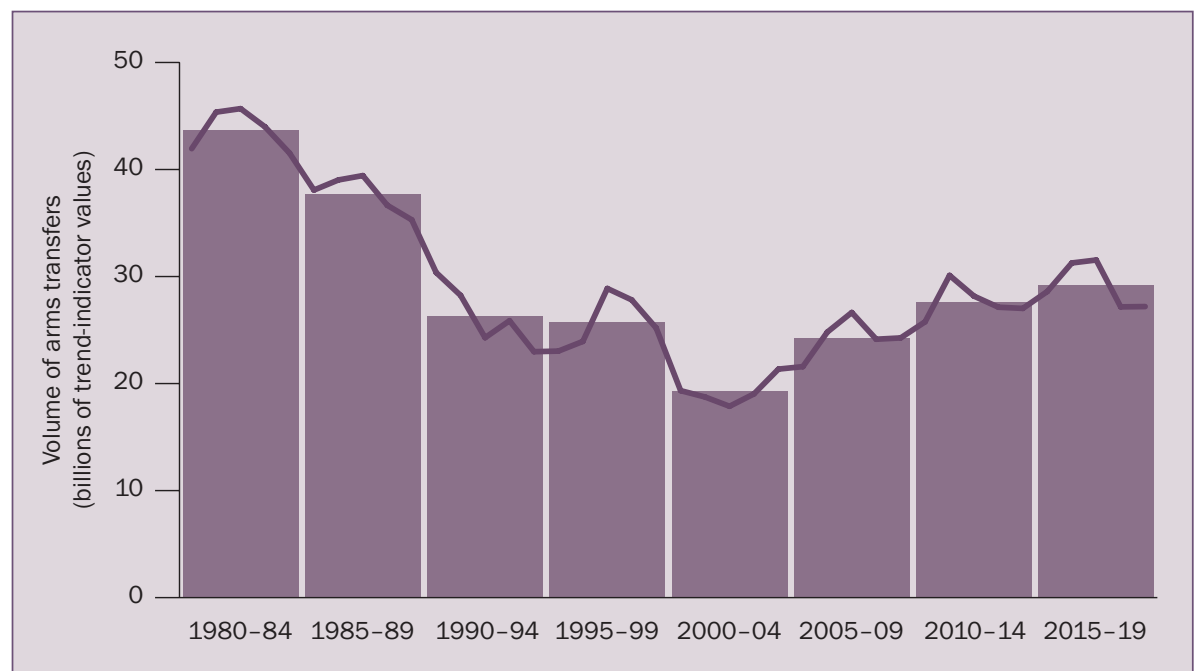

Figure 1. The trend in international transfers of major arms, 1980-2019

Note: The bar graph shows the average volume of arms transfers for 5 -year periods and the line graph shows the annual totals. The SIPRI trend-indicator value (TIV) is a measure of the volume of international transfers of major arms. The method used to calculate the SIPRI TIV is described on the Arms Transfers Database web page.

Source: SIPRI Arms Transfers Database, Mar. 2020.

\footnotetext{
${ }^{1}$ For further detail on the SIPRI Arms Transfers Database see p. 12.
}

\section{KEY FACTS}

- The volume of international transfers of major arms in 2015-19 was 5.5 per cent higher than in 2010-14 and 20 per cent higher than in 2005-2009.

- The five largest arms exporters in 2015-19 were the United States, Russia, France, Germany and China. Together, they accounted for 76 per cent of all arms exports in 2015-19.

- In 2015-19 US arms exports accounted for 36 per cent of the global total and were 23 per cent higher than in 2010-14.

- Russian arms exports decreased by 18 per cent between 2010-14 and 2015-19. - French, German and Chinese arms exports in 2015-19 were higher than in 2010-14, with respective increases of 72,17 and 6.3 per cent.

- The five largest arms importers in 2015-19-Saudi Arabia, India, Egypt, Australia and China-together received 36 per cent of all arms imports. - The main recipient region in 2015-19 was Asia and Oceania (accounting for 41 per cent of global arms imports), followed by the Middle East (35 per cent), Europe (11 per cent), Africa (7.2 per cent) and the Americas (5.7 per cent).

- Between 2010-14 and 2015-19, there were increases in arms imports by states in the Middle East (by 61 per cent) and by states in Europe (3.2 per cent). There were decreases in arms imports by states in Africa (-16 per cent), the Americas ( -40 per cent) and Asia and Oceania (-7.9 per cent). 
Table 1. The 25 largest exporters of major arms and their main clients, 2015-19

Note: Percentages below 10 are rounded to 1 decimal place; percentages over 10 are rounded to whole numbers.

\begin{tabular}{|c|c|c|c|c|c|c|c|}
\hline & \multirow[b]{2}{*}{ Exporter } & \multicolumn{2}{|c|}{$\begin{array}{l}\text { Share of } \\
\text { arms exports (\%) }\end{array}$} & \multirow{2}{*}{$\begin{array}{l}\text { Per cent } \\
\text { change from } \\
2010-14 \text { to } \\
2015-19^{a}\end{array}$} & \multicolumn{3}{|c|}{$\begin{array}{l}\text { Main clients (share of exporter's total exports, \%), } \\
\text { 2015-19 }\end{array}$} \\
\hline & & 2015-19 & 2010-14 & & 1 st & 2nd & $3 r d$ \\
\hline 1 & United States & 36 & 31 & 23 & Saudi Arabia (25) & Australia (9.1) & UAE (6.4) \\
\hline 2 & Russia & 21 & 27 & -18 & India (25) & China (16) & Algeria (14) \\
\hline 3 & France & 7.9 & 4.8 & 72 & Egypt (26) & Qatar (14) & India (14) \\
\hline 4 & Germany & 5.8 & 5.3 & 17 & South Korea (18) & Greece (10) & Algeria (8.1) \\
\hline 5 & China & 5.5 & 5.5 & 6.3 & Pakistan (35) & Bangladesh (20) & Algeria (9.9) \\
\hline 6 & United Kingdom & 3.7 & 4.6 & -15 & Saudi Arabia (41) & Oman (14) & USA (9.1) \\
\hline 7 & Spain & 3.1 & 2.9 & 13 & Australia (33) & Singapore (13) & Turkey (11) \\
\hline 8 & Israel & 3.0 & 1.8 & 77 & India (45) & Azerbaijan (17) & Viet Nam (8.5) \\
\hline 9 & Italy & 2.1 & 2.7 & -17 & Turkey (20) & Pakistan (7.5) & Saudi Arabia (7.2) \\
\hline 10 & South Korea & 2.1 & 0.9 & 143 & UK (17) & Iraq (14) & Indonesia (13) \\
\hline 11 & Netherlands & 1.9 & 2.0 & -2.8 & Indonesia (17) & USA (14) & Jordan (13) \\
\hline 12 & Ukraine & 1.0 & 2.8 & -63 & China (31) & Russia (20) & Thailand (17) \\
\hline 13 & Switzerland & 0.9 & 0.9 & 2.6 & Australia (18) & China (14) & Saudi Arabia (14) \\
\hline 14 & Turkey & 0.8 & 0.5 & 86 & Turkmenistan (25) & Oman (12) & Pakistan (12) \\
\hline 15 & Sweden & 0.6 & 1.8 & -65 & USA (22) & Algeria (12) & UAE (10) \\
\hline 16 & Canada & 0.6 & 0.9 & -33 & Saudi Arabia (34) & India (11) & UAE (10) \\
\hline 17 & Norway & 0.4 & 0.6 & -30 & Oman (35) & USA (20) & Finland (14) \\
\hline 18 & UAE & 0.4 & 0.2 & 86 & Egypt (41) & Algeria (13) & Unidentified state (12) \\
\hline 19 & Australia & 0.3 & 0.3 & 11 & USA (42) & Indonesia (18) & Canada (18) \\
\hline 20 & Belarus & 0.3 & 0.5 & -23 & Viet Nam (31) & Sudan (16) & Serbia (15) \\
\hline 21 & Czechia & 0.3 & 0.1 & 453 & Iraq (39) & USA (17) & Ukraine (9.0) \\
\hline 22 & South Africa & 0.3 & 0.5 & -36 & USA (23) & UAE (20) & Malaysia (11) \\
\hline 23 & India & 0.2 & 0.0 & 426 & Myanmar (46) & Sri Lanka (25) & Mauritius (14) \\
\hline 24 & Brazil & 0.2 & 0.2 & 6.8 & Afghanistan (38) & Indonesia (17) & Lebanon (11) \\
\hline 25 & Portugal & 0.2 & 0.0 & 1239 & Romania (95) & Uruguay (2.9) & Cabo Verde (1.2) \\
\hline
\end{tabular}

$\mathrm{UAE}=$ United Arab Emirates.

${ }^{a}$ Figures show the change in volume of the total arms exports per exporter between the 2 periods.

Source: SIPRI Arms Transfers Database, Mar. 2020.

THE EXPORTERS, 2015-19

SIPRI has identified 68 states as exporters of major arms in 2015-19. The five largest suppliers of arms during that period-the USA, Russia, France, Germany and China-accounted for 76 per cent of all arms exports (see figure 2 and table 1). The top five in 2015-19 were the same as in 2010-14, but their combined total exports of major arms were 9.5 per cent higher. France had the highest increase in arms exports among the top five. US, German and Chinese arms exports also rose, while Russian arms exports fell (see figure 3). The top 25 arms exporters accounted for 99 per cent of the world's major arms exports in 2015-19 (see table 1). States in North America and Europe accounted for 87 per cent of all arms exports. 


\section{The United States}

The USA was the top arms exporter in 2015-19 and delivered major arms to 96 states. This is a far higher number of destinations for arms exports than any other supplier. US arms exports grew by 23 per cent between $2010-14$ and 2015-19 and the USA's share of total global arms exports rose from 31 per cent to 36 per cent. The gap in total arms exports between the USA and Russiathe second-largest exporter-has grown rapidly: in 2010-14 US exports of major arms were 17 per cent higher than those of Russia, whereas in 2015-19 they were 76 per cent higher.

The Middle East accounted for 51 per cent of total US arms exports in 2015-19. US arms exports to the region increased by 79 per cent between 2010-14 and 2015-19. Saudi Arabia was the largest recipient of US arms in 2015-19 and accounted for 25 per cent of US arms exports, compared with 7.4 per cent in 2010-14. Although the US Congress discussed the possibility of placing some restrictions on arms exports to Saudi Arabia in 2019, deliveries-including the delivery of 30 out of 154 combat aircraft ordered in 2011-continued throughout 2019. In addition, in 2019 the US Government authorized the sale of an estimated 59000 guided bombs to Saudi Arabia.

Arms exports to Asia and Oceania accounted for 30 per cent of total US arms exports in 2015-19. US arms exports to the region were down by 20 per cent on $2010-14$ as a result of decreases in arms exports to India ( -51 per cent), Pakistan (-92 per cent), Singapore (-60 per cent), South Korea ( -34 per cent) and Taiwan (-38 per cent). These decreases were partly offset by increases in US arms exports to Australia, which rose by 41 per cent (making Australia the second-largest importer of US arms in 2015-19), and to Japan, which rose by 85 per cent.

Arms exports to Europe accounted for 13 per cent of US arms exports in 2015-19, an increase of 45 per cent on 2010-14. US arms exports to Africa
Figure 2. Global share of major arms exports by the 10 largest exporters, 2015-19

Source: SIPRI Arms Transfers Database, Mar. 2020.

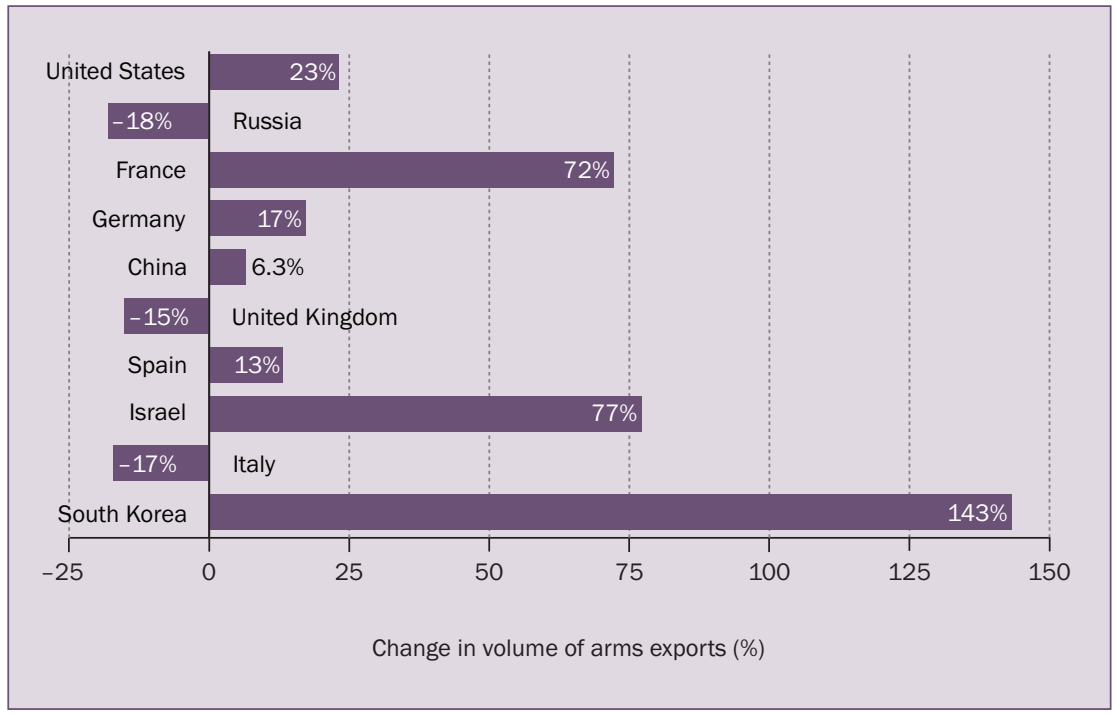

Figure 3. Changes in volume of major arms exports since 2010-14 by the 10 largest exporters in 2015-19

Source: SIPRI Arms Transfers Database, Mar. 2020. 
increased by 10 per cent between 2010-14 and 2015-19, while those to the Americas decreased by 20 per cent.

\section{Russia}

Russian arms exports accounted for 21 per cent of total arms exports in 2015-19 but were 18 per cent lower than in 2010-14. Although India remained the main recipient of Russian arms in 2015-19, accounting for 25 per cent of the total, Russian arms exports to India fell by 47 per cent between 2010-14 and 2015-19.

In 2015-19 Russia delivered major arms to 47 states. A total of 55 per cent of its arms exports went to its three main recipients: India, China and Algeria (see table 1). At the regional level, states in Asia and Oceania accounted for 57 per cent of Russian arms exports in 2015-19, the Middle East for 19 per cent, Africa for 17 per cent, Europe for 5.7 per cent and the Americas for 0.8 per cent.

Russian exports of major arms to the Middle East increased by 30 per cent between 2010-14 and 2015-19. In 2015-19 Egypt and Iraq were the main recipients of Russian arms exports to the Middle East, accounting, respectively, for 49 and 29 per cent of Russian arms exports to the region. Deliveries to Iraq were up by 212 per cent on 2010-14, while those to Egypt were up by 191 per cent. Although Russian forces have been supporting the Syrian Government in the conflict in Syria since 2015, Russian arms deliveries to Syria fell by 87 per cent between 2010-14 and 2015-19, and it accounted for only 3.9 per cent of Russian arms exports to the Middle East and 0.7 per cent of total Russian arms exports in 2015-19.

\section{The European Union and West European countries}

The combined arms exports by European Union member states accounted for 26 per cent of the global total in 2015-19 and were 9.0 per cent higher than in 2010-14. The top five West European arms exporters-France, Germany, the United Kingdom, Spain and Italy-together accounted for 23 per cent of global arms exports in 2015-19, compared with 20 per cent in 2010-14. French, German and Spanish arms exports increased between the two periods, while British and Italian arms exports decreased (see figure 3).

In 2015-19 French arms exports reached their highest level for any fiveyear period since 1990 and accounted for 7.9 per cent of the global total. After a fall of 31 per cent between 2005-2009 and 2010-14, French arms exports rose by 72 per cent between $2010-14$ and 2015-19. French arms exports to the Middle East were 363 per cent higher than in 2010-14. The region accounted for 52 per cent of French arms exports in 2015-19, followed by Asia and Oceania with 30 per cent.

France delivered major arms to 75 states in 2015-19. The three main recipients were Egypt, Qatar and India, which together accounted for 54 per cent of French arms exports (see table 1). 2015-19 was the first five-year period in which these countries had been among the main recipients of French arms since the 1980s. Deliveries of Rafale combat aircraft to these three countries accounted for nearly a quarter of French arms exports in 2015-19. At the end of 2019 there were outstanding orders for a wide range of French major arms, 
including Rafale combat aircraft to India and Qatar, submarines to Brazil and India, and frigates to Egypt, Malaysia and the United Arab Emirates (UAE). This indicates that France's arms exports will continue to be at a relatively high level for at least the next five years.

German arms exports accounted for 5.8 per cent of the global total in 2015-19 and were 17 per cent higher than in 2010-14. In 2015-19 a total of 30 per cent of German arms exports went to Asia and Oceania, 26 per cent to other states in Europe, 24 per cent to the Middle East, 11 per cent to the Americas and 8.3 per cent to Africa.

In 2015-19 Germany delivered four submarines to South Korea, three each to Egypt and Greece, two each to Colombia and Italy, and one to Israel. Together, these deliveries accounted for 39 per cent of German arms exports in 2015-19.

The UK was the world's sixth-largest arms exporter in 2015-19 and accounted for 3.7 per cent of total arms exports. British arms exports fell by 15 per cent between 2010-14 and 2015-19, primarily as a result of decreases in its arms exports to Saudi Arabia, India and the USA.

\section{Other top 10 suppliers}

There were three countries outside Europe and North America among the top 10 arms exporters in 2015-19: China, Israel and South Korea.

China was the world's fifth-largest arms exporter in 2015-19 and accounted for 5.5 per cent of total arms exports. After an increase of 133 per cent between 2005-2009 and 2010-14, Chinese arms exports grew by only 6.3 per cent between 2010-14 and 2015-19. In 2015-19 Asia and Oceania accounted for 74 per cent of Chinese arms exports, Africa for 16 per cent and the Middle East for 6.7 per cent. The number of countries to which China delivers arms has grown significantly: from 40 in $2010-14$ to 53 in $2015-19$. Pakistan was the main recipient (35 per cent) in 2015-19, as it has been for all five-year periods since 1991.

Israel was the eighth-largest arms supplier in 2015-19. Its arms exports accounted for 3.0 per cent of the global total and were 77 per cent higher than in 2010-14. Although Israel has ranked higher than eighth in some earlier five-year periods, the volume of Israeli arms exports in 2015-19 was the highest ever.

South Korea was the 10th-largest arms exporter in 2015-19 with a 2.1 per cent share of the global total. Its arms exports increased by 143 per cent between 2010-14 and 2015-19, the highest level of increase among exporters in the top 10. However, its imports remained substantially higher than its exports. The number of countries to which South Korea delivered arms rose from 7 in 2010-14 to 17 in 2015-19. In 2015-19 Asia and Oceania accounted for 50 per cent of South Korean arms exports, Europe for 24 per cent and the Middle East for 17 per cent. Unlike in the two previous five-year periods, in which well over half of South Korean arms exports went to Turkey, in 2015-19 the distribution of South Korean arms exports was spread far more widely. The largest recipient (the UK) accounted for only 17 per cent of South Korean arms exports. 
Table 2. The 40 largest importers of major arms and their main suppliers, 2015-19

Note: Percentages below 10 are rounded to 1 decimal place; percentages over 10 are rounded to whole numbers.

\begin{tabular}{|c|c|c|c|c|c|c|c|}
\hline & \multirow[b]{2}{*}{ Importer } & \multicolumn{2}{|c|}{$\begin{array}{l}\text { Share of } \\
\text { arms imports (\%) }\end{array}$} & \multirow{2}{*}{$\begin{array}{l}\text { Per cent } \\
\text { change from } \\
2010-14 \text { to } \\
2015-19^{a}\end{array}$} & \multicolumn{3}{|c|}{$\begin{array}{l}\text { Main suppliers (share of importer's total imports, \%), } \\
\text { 2015-19 }\end{array}$} \\
\hline & & 2015-19 & 2010-14 & & 1 st & 2 nd & $3 \mathrm{rd}$ \\
\hline 1 & Saudi Arabia & 12 & 5.6 & 130 & USA (73) & UK (13) & France (4.3) \\
\hline 2 & India & 9.2 & 14 & -32 & Russia (56) & Israel (14) & France (12) \\
\hline 3 & Egypt & 5.8 & 1.9 & 212 & France (35) & Russia (34) & USA (15) \\
\hline 4 & Australia & 4.9 & 3.7 & 40 & USA (68) & Spain (21) & France (3.6) \\
\hline 5 & China & 4.3 & 4.4 & 3.3 & Russia (76) & France (8.8) & Ukraine (6.9) \\
\hline 6 & Algeria & 4.2 & 2.6 & 71 & Russia (67) & China (13) & Germany (11) \\
\hline 7 & South Korea & 3.4 & 3.5 & 3.3 & USA (55) & Germany (30) & Spain $(7.8)$ \\
\hline 8 & UAE & 3.4 & 4.4 & -18 & USA (68) & France (11) & Netherlands (3.4) \\
\hline 9 & Iraq & 3.4 & 1.8 & 98 & USA (45) & Russia (34) & South Korea (8.6) \\
\hline 10 & Qatar & 3.4 & 0.5 & 631 & USA (50) & France (34) & Germany (9.2) \\
\hline 11 & Pakistan & 2.6 & 4.5 & -39 & China (73) & Russia (6.6) & Italy (6.1) \\
\hline 12 & Viet Nam & 2.2 & 2.6 & -9.3 & Russia (74) & Israel (12) & Belarus (4.9) \\
\hline 13 & United States & 2.0 & 3.3 & -37 & Germany (21) & UK (17) & Netherlands (13) \\
\hline 14 & Israel & 2.0 & 0.7 & 181 & USA (78) & Germany (16) & Italy (6.2) \\
\hline 15 & Turkey & 1.8 & 3.7 & -48 & USA (38) & Italy (24) & Spain (19) \\
\hline 16 & Japan & 1.8 & 1.1 & 72 & USA (96) & $\mathrm{UK}(2.4)$ & Sweden (1.6) \\
\hline 17 & Indonesia & 1.8 & 1.9 & -4.6 & USA (20) & Netherlands (18) & South Korea (16) \\
\hline 18 & United Kingdom & 1.7 & 1.5 & 17 & USA (67) & South Korea (21) & Germany (4.7) \\
\hline 19 & Singapore & 1.7 & 2.5 & -29 & USA (37) & Spain (24) & France (18) \\
\hline 20 & Bangladesh & 1.6 & 0.9 & 93 & China (72) & Russia (15) & $\mathrm{UK}(2.4)$ \\
\hline 21 & Italy & 1.5 & 0.6 & 175 & USA (62) & Germany (25) & Israel (6.5) \\
\hline 22 & Thailand & 1.2 & 0.8 & 67 & South Korea (21) & China (21) & Ukraine (14) \\
\hline 23 & Oman & 1.2 & 1.0 & 24 & UK (45) & USA (13) & Norway (12) \\
\hline 24 & Norway & 1.1 & 0.7 & 67 & USA (77) & Italy (7.9) & South Korea (7.2) \\
\hline 25 & Kazakhstan & 1.0 & 0.3 & 238 & Russia (90) & Spain (3.2) & China (2.1) \\
\hline 26 & Taiwan & 0.9 & 1.7 & -41 & USA (100) & - & - \\
\hline 27 & Canada & 0.9 & 0.9 & 4.2 & USA (56) & Netherlands (11) & Israel (9.6) \\
\hline 28 & Greece & 0.9 & 0.7 & 39 & Germany (64) & USA (19) & $\mathrm{UK}(7.5)$ \\
\hline 29 & Afghanistan & 0.9 & 1.5 & -38 & USA (87) & Brazil (8.8) & Canada (1.2) \\
\hline 30 & Azerbaijan & 0.8 & 1.5 & -40 & Israel (60) & Russia (31) & Turkey (3.2) \\
\hline 31 & Morocco & 0.8 & 2.3 & -62 & USA (91) & France (8.9) & $\mathrm{UK}(0.3)$ \\
\hline 32 & Jordan & 0.8 & 0.5 & 54 & USA (30) & Netherlands (30) & Russia (10) \\
\hline 33 & Myanmar & 0.7 & 1.1 & -32 & China (49) & Russia (16) & India (14) \\
\hline 34 & Brazil & 0.6 & 1.0 & -37 & France (26) & USA (20) & UK (17) \\
\hline 35 & Philippines & 0.6 & 0.1 & 403 & South Korea (32) & Indonesia (21) & USA (19) \\
\hline 36 & Mexico & 0.6 & 0.5 & 17 & USA (64) & Spain (9.5) & France (8.5) \\
\hline 37 & Belarus & 0.6 & 0.2 & 186 & Russia (98) & Ukraine (1.2) & China (0.5) \\
\hline 38 & Netherlands & 0.6 & 0.7 & -21 & USA (76) & Germany (13) & Italy (7.6) \\
\hline 39 & Kuwait & 0.5 & 0.7 & -22 & USA (70) & France (9.5) & Switzerland (7.1) \\
\hline 40 & Poland & 0.5 & 0.6 & -14 & USA (29) & Germany (18) & Italy (14) \\
\hline
\end{tabular}

$\mathrm{UAE}=$ United Arab Emirates.

${ }^{a}$ Figures show the change in volume of the total arms imports per importer between the 2 periods.

Source: SIPRI Arms Transfers Database, Mar. 2020. 


\section{THE IMPORTERS, 2015-19}

SIPRI has identified 160 states as importers of major arms in 2015-19. The top five arms importers-Saudi Arabia, India, Egypt, Australia and Chinaaccounted for 36 per cent of total arms imports in 2015-19 (see figure 4 and table 2). Of these, Saudi Arabia, India and China were among the top five importers in both 2010-14 and 2015-19. At the regional level, Asia and Oceania accounted for 41 per cent of arms imports in 2015-19, followed by the Middle East (35 per cent), Europe (11 per cent), Africa (7.2 per cent) and the Americas (5.7 per cent; see figure 5).

\section{Africa}

Arms imports by African states decreased by 16 per cent between 2010-14 and 2015-19. Russia accounted for 49 per cent of arms exports to the region, the USA for 14 per cent and China for 13 per cent.

\section{North Africa}

North Africa accounted for 74 per cent of African arms imports in 2015-19. Algeria alone accounted for 79 per cent of North African arms imports. Algeria's arms imports were up by 71 per cent on 2010-14, making it the sixth-largest arms importer in the world in 2015-19. The increase occurred in the context of Algeria's long-standing tensions with Morocco, internal tensions and concerns about the conflicts in neighbouring Mali and Libya (see box 1). As in 2010-14, Russia remained the largest arms supplier to Algeria in 2015-19, accounting for 67 per cent of Algerian arms imports, followed by China (13 per cent) and Germany (11 per cent).

\section{Sub-Saharan Africa}

States in sub-Saharan Africa accounted for 26 per cent of African arms imports in 2015-19. Taken together, the arms imports by states in the subregion were 49 per cent lower in 2015-19 than in 2010-14 and at the lowest level since 1995-99. In 2015-19 Russia accounted for 36 per cent of arms imports by states in the subregion, China for 19 per cent and France for 7.6 per cent. The five largest arms importers in sub-Saharan Africa-Angola, Nigeria, Sudan, Senegal and Zambia-accounted for 63 per cent of all arms imports to the subregion. Angola accounted for 27 per cent of arms imports to sub-Saharan Africa and was the 42ndlargest arms importer globally. Even though Angola's economy was in recession, its arms imports were 2120 per cent higher in 2015-19 than in 2010-14.

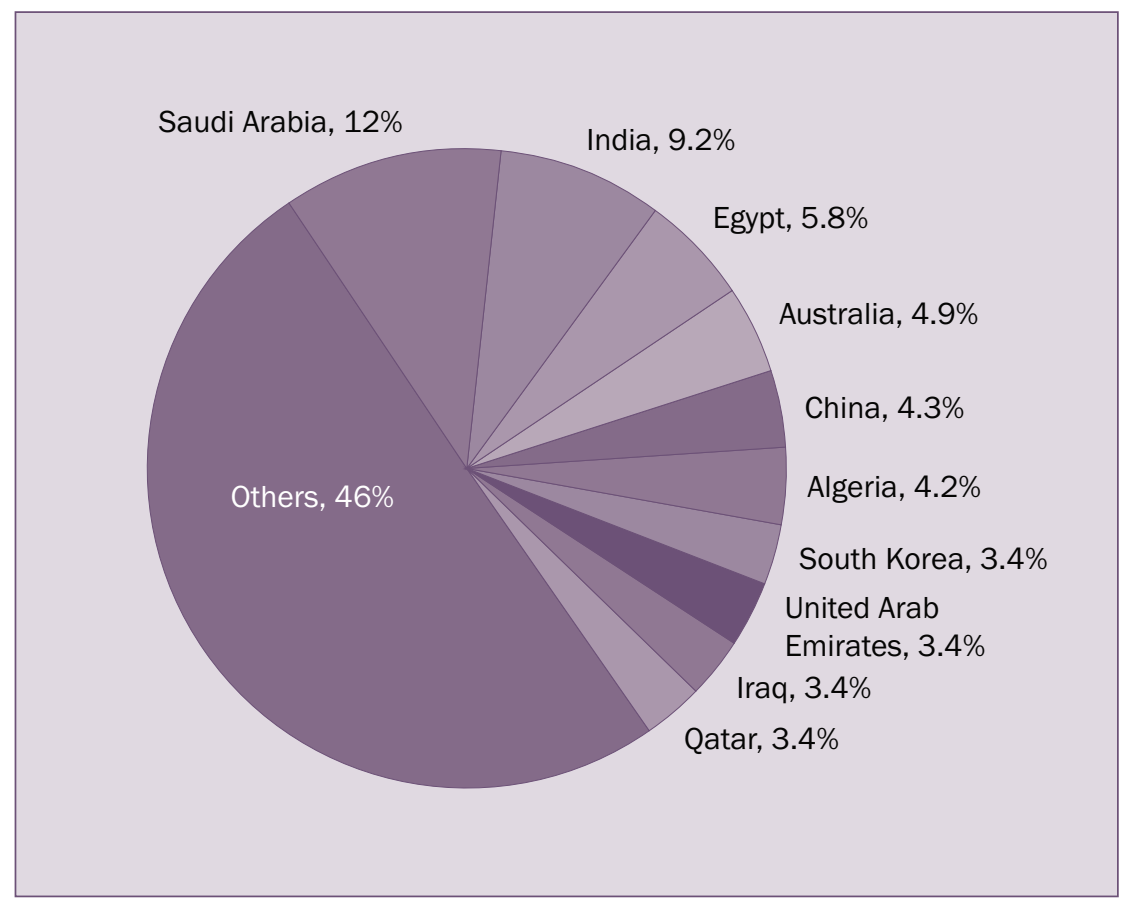

Figure 4. Global share of major arms imports by the 10 largest importers, 2015-19

Source: SIPRI Arms Transfers Database, Mar. 2020. 
Box 1. Arms transfers and the conflict in Libya

The war between the internationally recognized Libyan Government of National Accord (GNA) and the Libyan National Army (LNA) that started in 2014 continued in 2019. Both sides have received weapons from abroad in violation of the 2011 United Nations arms embargo on Libya, but no country has been sanctioned for this.

Details about these arms deliveries are uncertain and the volume cannot be estimated. For example, in 2019 the GNA received an unknown number of armoured vehicles and armed unmanned aerial vehicles (UAVs) from Turkey. In 2015-19 the LNA received armoured vehicles from Jordan and the United Arab Emirates (UAE), combat helicopters from Belarus, supplied via the UAE, and combat aircraft from Egypt. Combat aircraft and armed UAVs originating from the UAE have been used in the fighting, including in 2019. It is unclear whether they are being operated by the UAE or whether the UAE has supplied them to the LNA. The UAE's involvement in Libya is part of its assertive foreign policy, which also includes its military intervention in Yemen. In 2015-19 the UAE accounted for 3.4 per cent of global arms imports. It received major arms from a total of 17 countries in 2015-19 but the United States accounted for 68 per cent of its arms imports. In 2019, when foreign military involvement in Libya was condemned by the UN Security Council, the UAE had major arms import deals ongoing with Australia, Brazil, Canada, China, France, Russia, South Africa, Spain, Sweden, Turkey, the United Kingdom and the USA.

The increase can largely be attributed to the delivery of 12 combat aircraft from Russia.

South Africa was the largest arms importer in sub-Saharan Africa in 2005-2009, mainly as a result of deliveries of frigates and submarines from Germany and combat aircraft from Sweden. In 2010-14 its arms imports fell by 78 per cent and in 2015-19 they were nearly at zero. This sharp decrease was partly a result of South Africa's severe economic problems, which also meant that it lacked the funds to operate half of its fleet of combat aircraft supplied by Sweden.

\section{Asia and Oceania}

Arms imports by states in Asia and Oceania decreased by 7.9 per cent between 2010-14 and 2015-19. Of the 10 largest importers in 2015-19, four were in Asia and Oceania: India, Australia, China and South Korea. Russia accounted for 29 per cent of arms imports by states in the region, the USA for 27 per cent and China for 10 per cent.

\section{India and Pakistan}

Between 2010-14 and 2015-19, arms imports by India and Pakistan decreased by 32 and 39 per cent, respectively. While both countries have long-standing aims to produce their own major arms, they remain largely dependent on imports and have substantial outstanding orders and plans for imports of all types of major arms.

Russia was the largest supplier to India in 2010-14 and 2015-19, but deliveries fell by 47 per cent and its share of total Indian arms imports went from 72 to 56 per cent. The USA became the second-largest arms supplier to India in 2010-14 as the security relationship between the two countries developed into a strategic partnership. However, in 2015-19 India continued with its policy of supplier diversification, and imports of arms from the USA were 51 per cent lower than in 2010-14. In contrast, arms imports from Israel and France increased, by 175 and 715 per cent, respectively, making them the second- and third-largest suppliers of major arms to India in 2015-19 (see table 2). 
China accounted for 51 per cent of Pakistan's arm imports in 2010-14 and for 73 per cent in 2015-19. The overall decrease in Pakistan's arms imports was linked to the USA's decision to stop military aid to Pakistan. The USA accounted for 30 per cent of Pakistan's arms imports in 2010-14 but for only 4.1 per cent in 2015-19. Pakistan continued to import arms from European states in 2015-19 and also strengthened its arms import relations with Turkey with orders for 30 combat helicopters and 4 frigates in 2018.

Cross-border attacks between India and Pakistan intensified in early 2019. Pakistan reportedly used combat aircraft imported from China, equipped with Russian engines, and combat aircraft from the USA supported by airborne early warning and control aircraft from Sweden. India reportedly used combat aircraft imported from France and Russia, guided bombs from Israel and artillery from Sweden.

\section{East Asia}

Arms imports by East Asian states increased by 3.0 per cent between 2010-14 and 2015-19. China, which accounted for 4.3 per cent of global arms imports in 2015-19, was the largest arms importer in the subregion. The bulk of its imports were for air defence systems, combat aircraft and engines for combat aircraft from Russia. It has, however, developed an advanced arms industry and has become far less reliant on arms imports from Russia.

Arms imports by Taiwan in 2015-19 were 41 per cent lower than in 2010-14. However, in 2019 it placed orders for 66 F-16V combat aircraft and 108 tanks from the USA. The USA had initially been reluctant to agree to these arms sales because of the damage previous arms sales to Taiwan had caused to US-Chinese relations.

Arms imports by Japan increased by 72 per cent between 2010-14 and 2015-19 and are likely to continue to rise based on new orders for arms from the USA, including an order in 2019 for 105 F-35 combat aircraft.

\section{Central America and the Caribbean, and South America}

Arms imports by states in Central America and the Caribbean increased by 23 per cent between 2010-14 and 2015-19. Mexico accounted for 70 per cent of all arms imports to the subregion in 2015-19. The 17 per cent increase in Mexico's arms imports between 2010-14 and 2015-19 coincided with its ongoing military operations against drug cartels.

Arms imports by South American states fell by 15 per cent between 2005-2009 and 2010-14, and by 59 per cent between 2010-14 and 2015-19. In

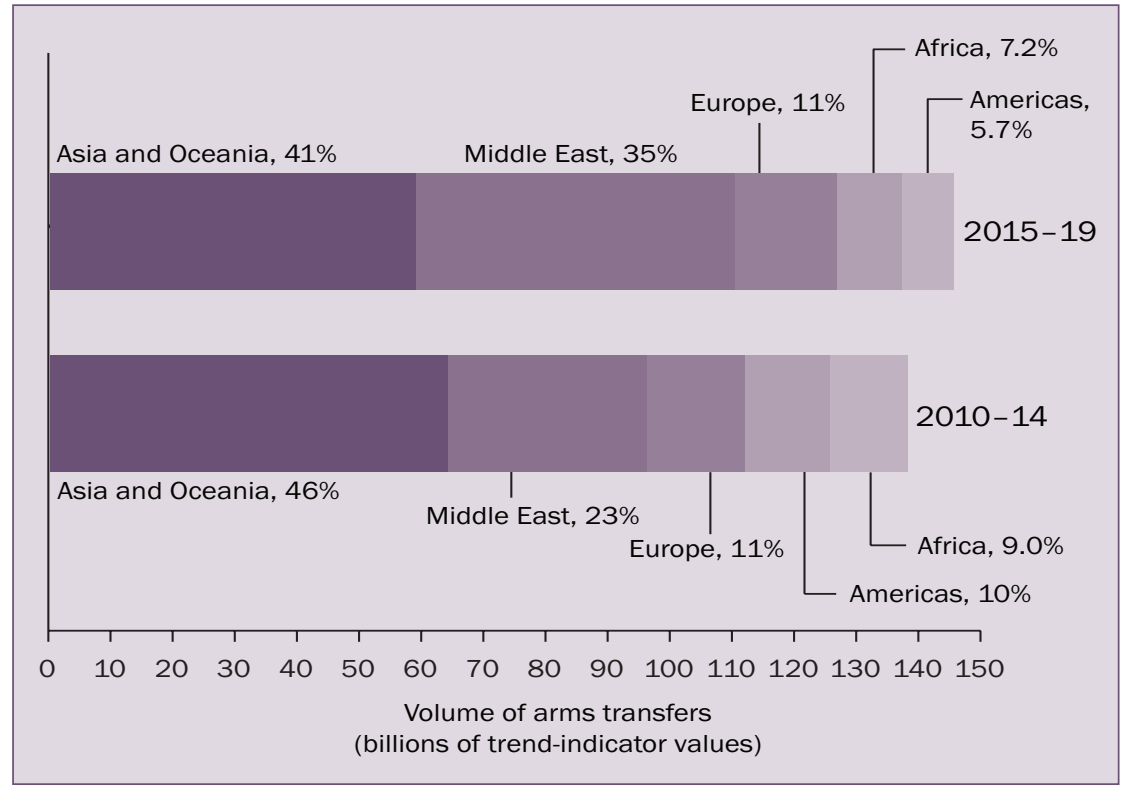

Figure 5. The importers of major arms, by region, 2015-19 and 2010-14, per cent of global share

Note: The SIPRI trend-indicator value (TIV) is a measure of the volume of international transfers of major weapons. The method used to calculate the SIPRI TIV is described on the Arms Transfers Database web page.

Source: SIPRI Arms Transfers Database, Mar. 2020. 
2015-19 the USA accounted for 19 per cent of the subregion's arms imports, France for 16 per cent and Italy for 8.6 per cent.

Venezuela was the largest arms importer in South America in 2010-14, when it was re-equipping with mainly Russian arms. However, in 2015-19 Venezuela's arms imports were 88 per cent lower than in 2010-14 as it continued to be affected by a severe economic crisis.

Although Brazil's arms imports were 37 per cent lower than in 2010-14, it was the largest arms importer in South America in 2015-19 and accounted for 31 per cent of the subregion's arms imports. By the end of 2019 it also had the largest outstanding orders for arms-including for combat aircraft from Sweden and submarines from France-of any state in the subregion.

\section{Europe}

Arms imports by states in Europe fell by 37 per cent between $2005-2009$ and 2010-14. However, this downward trend reversed in 2015-19: arms imports by European states were 3.2 per cent higher than in 2010-14 and accounted for 11 per cent of the global total. The USA accounted for 41 per cent of the region's arms imports in 2015-19, Germany for 14 per cent and Russia for 10 per cent.

\section{Arms transfers and armed conflict in Europe}

Major arms were used in conflict in Europe in 2015-19: armed forces in Ukraine fought against separatists in the east of the country, and there were skirmishes between Armenia and Azerbaijan. Ukraine's arms imports were very low in 2015-19, despite the armed conflict there. Its largest arms imports included 50 second-hand armoured vehicles from Czechia and 210 anti-tank missiles from the USA.

Armenia's arms imports increased by 415 per cent between 2010-14 and 2015-19. Russia accounted for 94 per cent of its arms imports in 2015-19. Despite a fall of 40 per cent between 2010-14 and 2015-19, Azerbaijan's arms imports were 3.3 times higher than those of Armenia in 2015-19. Israel accounted for 60 per cent and Russia for 31 per cent of Azerbaijan's arms imports in 2015-19. Both Armenia and Azerbaijan imported missiles capable of attacking targets deep inside each other's territory.

\section{Re-equipping European air forces}

In many West and Central European states growing tensions with Russia and involvement in military air operations in the Middle East have contributed to a growing demand for new combat aircraft. In 2015-19, states in Western and Central Europe imported a total of 59 new combat aircraft. At the end of 2019, these states had outstanding orders for imports of 380 new combat aircraft (356 F-35s and 24 F-16s), most for delivery in 2020-29. All of these aircraft will be supplied by the USA and in most cases were selected over rival offers from France, Sweden and a consortium of British, German, Italian and Spanish companies supported by their respective governments. 


\section{The Middle East}

Arms imports by states in the Middle East were 61 per cent higher in 2015-19 than in 2010-14. Five of the world's top 10 arms-importing countries in 2015-19 were in the Middle East: Saudi Arabia, which received 35 per cent of arms transfers to the region, Egypt (16 per cent), the UAE (9.7 per cent), Iraq (9.7 per cent) and Qatar (9.6 per cent). The USA supplied 53 per cent of total arms transfers to the region, France 12 per cent and Russia 11 per cent. Qatari arms imports were 631 per cent higher than in 2010-14, and it entered the top 10 for the first time (see table 2).

\section{Saudi Arabia}

Arms imports by Saudi Arabia were 130 per cent higher in 2015-19 than in 2010-14. It was the world's largest arms importer in 2015-19 and accounted for 12 per cent of all imports of major arms. The USA was by far the largest arms supplier to Saudi Arabia in 2015-19, accounting for 73 per cent of Saudi Arabian arms imports, followed by the UK (13 per cent). Discussions in the USA, Canada and many West European states about restrictions on arms exports to Saudi Arabia continued in 2019 based on concerns that its military intervention in Yemen involved violations of international humanitarian law and was not conducive to ending the war there. However, Saudi Arabia continued to import arms from some of these states in 2019, including 30 combat aircraft and large numbers of missiles and guided bombs from the USA, armoured vehicles from Canada, armoured vehicles and patrol boats from France, and missiles and trainer aircraft from the UK. Unlike the other European suppliers among the top 10 arms exporters in 2015-19, Germany suspended the bulk of its-already limited-arms exports to Saudi Arabia.

China and Russia each accounted for less than 1 per cent of Saudi Arabia's arms imports in 2015-19. China has supplied armed unmanned aerial vehicles to Saudi Arabia since 2014. In 2019 Russia exported major arms (a small batch of rocket launchers) to Saudi Arabia for the first time.

\section{Turkey}

In 1995-99 Turkey was the third-largest arms importer in the world; by 2005-2009 it was the ninth largest and in 2015-19 it ranked 15th. In 2015-19 Turkey's arms imports were 48 per cent lower than in 2010-14, even though its military was fighting Kurdish rebels and was involved in the conflicts in Libya and Syria. The decrease was partly due to production delays in submarines from Germany, originally planned for delivery in 2015-19. In addition, in the past, Turkey imported most of its warships and armoured vehicles, but in 2015-19 it mainly procured these arms from its own industry.

In 2019 the USA blocked a planned sale of 100 F-35 combat aircraft to Turkey, which would have resulted in an increase in Turkish arms imports over the next five years. The USA stopped the deal after Turkey imported S-400 air defence systems from Russia in 2019. The USA had concerns that Russia's possible access to the Turkish S-400 systems could have allowed it to gather information on the F-35s had they been supplied to Turkey. Furthermore, several European states restricted their arms sales to Turkey in 2019 because of its actions against Kurdish groups in Syria. 
SIPRI is an independent international institute dedicated to research into conflict, armaments, arms control and disarmament. Established in 1966, SIPRI provides data, analysis and recommendations, based on open sources, to policymakers, researchers, media and the interested public.

\section{GOVERNING BOARD}

Ambassador Jan Eliasson, Chair (Sweden)

Dr Dewi Fortuna Anwar (Indonesia)

Dr Vladimir Baranovsky (Russia)

Espen Barth Eide (Norway) Jean-Marie Guéhenno (France)

Dr Radha Kumar (India)

Dr Patricia Lewis (Ireland/ United Kingdom)

Dr Jessica Tuchman Mathews (United States)

\section{DIRECTOR}

Dan Smith (United Kingdom)

\section{Egypt}

Egypt was the third-largest arms importer in the world in 2015-19. Its arms imports accounted for 5.8 per cent of the global total and were 212 per cent higher than in 2010-14. The upward trend in Egypt's arms imports coincides with its military involvement in Libya (see box 1) and in Yemen, and fighting with rebel groups in the Sinai Peninsula. It might also be linked to Egypt's concerns over the security of gas fields in the Mediterranean and water supply from the Nile Basin. The USA, which has been giving military aid to Egypt since 1978, was the largest arms exporter to Egypt for any five-year period between 1980 and 2014. Although US arms exports to Egypt remained stable in 2015-19, the USA was only the third-largest arms supplier to Egypt in the period and accounted for 15 per cent of its arms imports, down from 47 per cent in 2010-14. Because of frictions with the USA related to the military coup in Egypt in 2013, Egypt has intensified its efforts to procure arms from other suppliers. In 2015-19 a total of 35 per cent of Egyptian arms imports came from France, up from 2.3 per cent in 2010-14; Russia accounted for 34 per cent of Egyptian arms imports in 2015-19.

\section{About the SIPRI Arms Transfers Database}

From 9 March 2020 the freely accessible SIPRI Arms Transfers Database includes data on arms transfers for 1950-2019, which replaces all previous data on arms transfers published by SIPRI. The database aims to contribute to an understanding of the effects of arms flows on peace, stability and violent conflict. This Fact Sheet is intended to encourage the use of the database for further research, investigations, policymaking and public debate.

The SIPRI Arms Transfers Database is the only public resource that provides consistent information, often estimates, on all international transfers of major arms (including sales, gifts and production under licence) to states, international organizations and non-state groups since 1950. It is accessible on the Arms Transfers Database web page of the SIPRI website.

SIPRI statistical data on arms transfers relates to actual deliveries of major arms. SIPRI measures the volume of international transfers of major arms using a common unit-the trend-indicator value (TIV). The method used to calculate the SIPRI TIV is described on the Arms Transfers Database web page.

As the volume of deliveries can fluctuate significantly year-on-year, SIPRI presents data for five-year periods, giving a more stable measure of trends. Percentage shares presented in this Fact Sheet do not always add up to 100 per cent or to stated totals because of the conventions of rounding.

\section{ABOUT THE AUTHORS}

Aude Fleurant (Canada/France), Pieter D. Wezeman (Netherlands/Sweden) and Siemon T. Wezeman (Netherlands) are Senior Researchers, Diego Lopes Da Silva (Brazil) and Nan Tian (China/South Africa) are Researchers and Alexandra Kuimova (Russia) is a Research Assistant with the SIPRI Arms and Military Expenditure Programme.
STOCKHOLM INTERNATIONAL PEACE RESEARCH INSTITUTE Signalistgatan 9 SE-169 72 Solna, Sweden Telephone: +4686559700 Email:sipri@sipri.org Internet: www.sipri.org 